\title{
RUSLE model based Annual Soil Loss Quantification for soil erosion protection in Fincha Catchment, Abay River Basin, Ethiopia.
}

\author{
Habtamu Tamiru ${ }^{* 1}$, Meseret Wagari ${ }^{2}$
}

Wollega University, Department of Water Resources and Irrigation Engineering, P.O. Box 395, Oromia, Ethiopia

* Correspondence: habtamutami@wollegauniversity.edu.et, Tel.: +251912100945

\begin{abstract}
The quantity of soil loss as a result of soil erosion is dramatically increasing in catchment where land resources management is very weak. In this paper, a RUSLE model-based soil loss quantification technique is presented to estimate the annual soil loss and identify the severity of the erosion in the catchment. This study uses Fincha catchment in Abay river basin as the study area to quantify the annual soil loss by implementing Revised Universal Soil Loss Equation (RUSLE) model developed in ArcGIS version 10.4. Digital Elevation Model (12.5 x 12.5), LANDSAT 8 of Operational Land Imager (OLI) and Thermal Infrared Sensor (TIRS), Annual Rainfall of 10 stations and soil maps of the catchment were used as input parameters to generate the significant factors. Rainfall erosivity factor $(\mathrm{R})$, soil erodibility factor $(\mathrm{K})$, cover and management factor $(\mathrm{C})$, slope length and steepness factor (LS) and support practice factor (P) were used as soil loss quantification significant factors. A model builder for the RUSLE model was developed and raster map calculation algebra was applied in ArcGIS version 10.4 to quantify the total annual soil loss. It was found that the quantified average annual soil loss ranges from 0.0 to 76.5 tha- $1 \mathrm{yr}-1$ was obtained in the catchment. The area coverage of soil erosion severity with $55 \%, 35 \%$ and $10 \%$ as low to moderate, high and very high respectively were identified. The information about the spatial variation of soil loss severity map generated in RUSLE model has a paramount role to alert land resources managers and all stakeholders in controlling the effects via implementation of both structural and non-structural mitigations. The results of the RUSLE model can also be further considered along with the catchment for practical soil loss quantification that can help for protection practices.
\end{abstract}

Keywords: RUSLE, Quantification, Severity, Significant Factors, Soil Erosion, Soil Loss

\section{INTRODUCTION}

Soil erosion is one of the current challenging issues of agriculture causing soil degradation. The severity of soil erosion is very serious in a country where land management is very weak (Thapa, 2020). The decrease in agricultural productivity (Girmay et al., 2020), ecosystem disturbances, and water resources pollutions are some of the major ill impacts of soil erosion that are commonly happening in the world (Borrelli et al., 2020). The topographic conditions, land use land cover, the intensity of the rainfall, and the soil characteristics are major significant factors of soil erosion (Yan et al., 2018). The annual dramatic increment of the depletion of very important soil nutrients (fertility) exposes the residents of this catchment to high expenses of money (Panagos et al., 2018) to use artificial fertilizers to increase the yield. The intrusion of runoff from eroded soil into a water source (Hategekimana et al., 2020) invites harmful pollutants and chemicals to change both the 
physical and chemical properties of sources of water. Even if soil erosion is a globally happening natural hazard (Markose \& Jayappa, 2016) in the world, its effects are very serious in developing countries as a result of the inability of restorative lost soil and valuable nutrients. In Africa, soil erosion is one of the top-ranked problems affecting agricultural sectors (Yesuph \& Dagnew, 2019) and water resources such as lakes and reservoirs and Ethiopia is not exceptional in the problem. Throughout the world, researchers have been using different models for the assessment and investigation of soil loss risk. EUROPean Soil Erosion Model (EUROPSEM), Limburg Soil Erosion Model (LISEM), Soil and Water Assessment Tool (SWAT), and Water Erosion Prediction Project (WEAP) are commonly used soil loss model (Fayas et al., 2019).

The application of integrated Geographical Information System (GIS) and remote sensing technologies in areas of the earth's surfaces are getting global attention and are widely used (Enea et al., 2018), (Singh \& Panda, 2017). The simple empirical function called Universal Soil Loss Equation (USLE) is the most commonly used model for loss assessment and later changed into Revised Universal Soil Loss Equation (RUSLE) was adopted to different catchments in Ethiopia (Dinka, 2020). This paper was conducted in Fincha Catchment where the soil is highly vulnerable to erosion, however, where such studies are not undertaken. Knowing the information about the spatial variation of soil erosion severity is a very important tool for implementing a protective measure in land resource management (Yesuph \& Dagnew, 2019). In the Fincha catchment, two man-made reservoirs and a natural lake reservoir are there, and the majority of water sources in this catchment are serving as water supply sources.

As a result of the topographic conditions, the intensity of rainfall, a traditional way of agricultural practices, and the nature of the soil in this catchment; the majority of the agricultural lands are prone to water derived erosion. Therefore, for this particular study area, an integrated GIS and RUSLE model-based soil loss quantification model was used to develop a spatially varied soil erosion severity map which is very important for sustainable land resources management strategies.

\section{MATERIAL AND METHODS}

\subsection{Study Area}

This study area is conducted in the Fincha catchment (Fig.1) in Abay River basin, and particularly the study under consideration was delineated fixing the outlet at Fincha River. This delineated watershed is geographically found between 3700.06'00" E to 37033'18" E longitude and $09021^{\prime} 11^{\prime \prime} \mathrm{N}$ to $10001^{\prime} 00^{\prime \prime} \mathrm{N}$ latitude. The delineated watershed has a total area of $21.48 \mathrm{~km} 2$. 


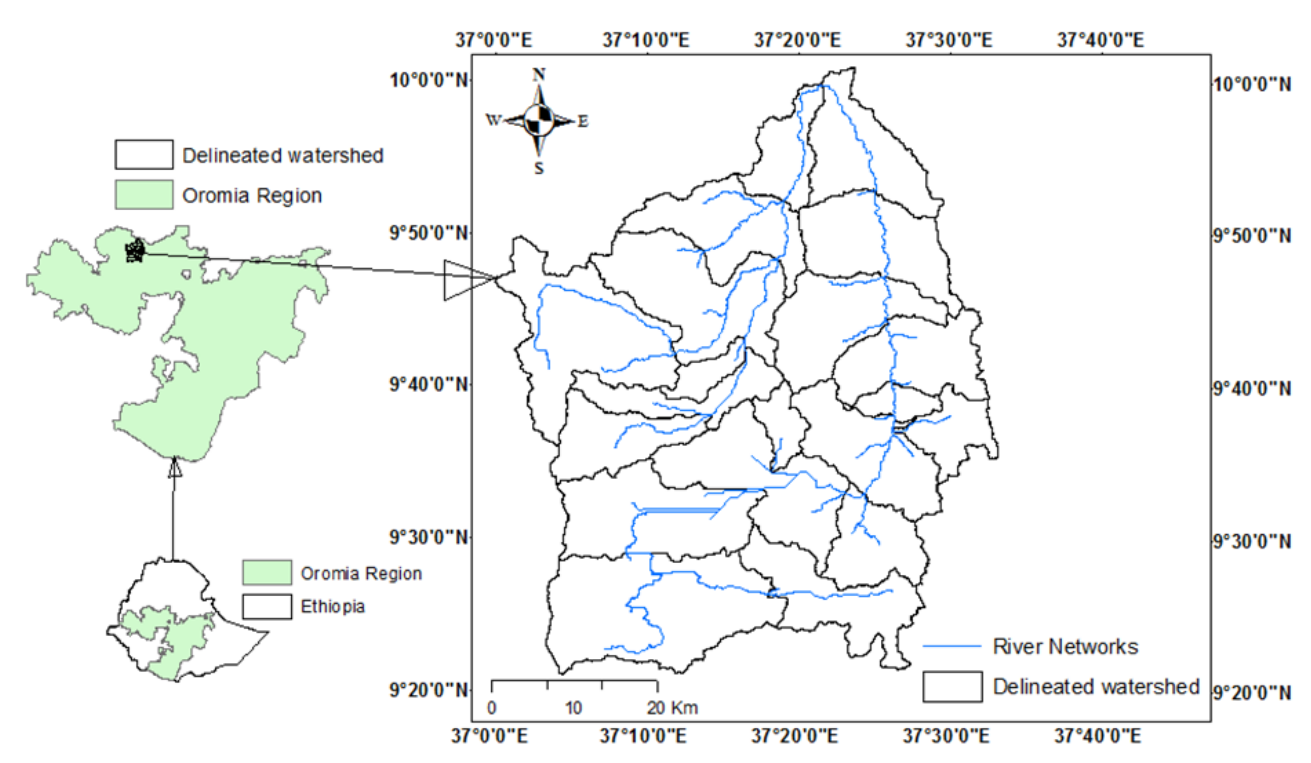

Figure 1: Geographical Location of the study area

\subsection{Data Collection}

To generate soil erosion significant factors namely; R-factor, P-factor, K-factor, LS-factor, and C-factor, annual average precipitation of 11 stations (Table 1 and Fig. 2) in Fincha catchment (Alibo, Kewo, Jardega, Sombo, Dedu, Achane, Shambu, Fincha, Kombolcha, Bila and Goben), land use land cover (LULC) derived from LANDSAT 8 OLI/TIRS, soil map obtained from ministry of Ethiopian geological Survey, and Digital Elevation Model (DEM) of (12.5 x 12.5) spatial resolution downloaded from Alaska University online facilities were used as input.

Table 1: Rainfall stations in and surrounding Fincha subbasin

\begin{tabular}{cccccc}
\hline No. & Station Name & Long & Lat & $\begin{array}{c}\text { Elevation } \\
(\mathrm{m})\end{array}$ & $\begin{array}{c}\text { Annual mean precipitation } \\
(\mathrm{mm})\end{array}$ \\
\hline 1 & Alibo & 37.0795 & 9.8904 & 2405.53 & 1754.2 \\
2 & Kewo & 37.5543 & 9.8271 & 2362.15 & 1353.65 \\
3 & Jardega & 37.0143 & 9.8065 & 2402.98 & 2030.93 \\
4 & Sombo & 37.0326 & 9.7424 & 2385.78 & 1988.75 \\
5 & Dedu & 37.5357 & 9.6889 & 2270.19 & 1491.6 \\
6 & Achane & 37.3216 & 9.6547 & 2398.33 & 1645.81 \\
7 & Shambu & 37.0943 & 9.5707 & 2556.4 & 1827.07 \\
8 & Fincha-a & 37.362 & 9.5659 & 2226.33 & 1528.11 \\
9 & Kombolcha & 37.4781 & 9.5097 & 2390.25 & 1621.3 \\
10 & Bila & 37.0279 & 9.2925 & 2114.34 & 1728.16 \\
\hline
\end{tabular}




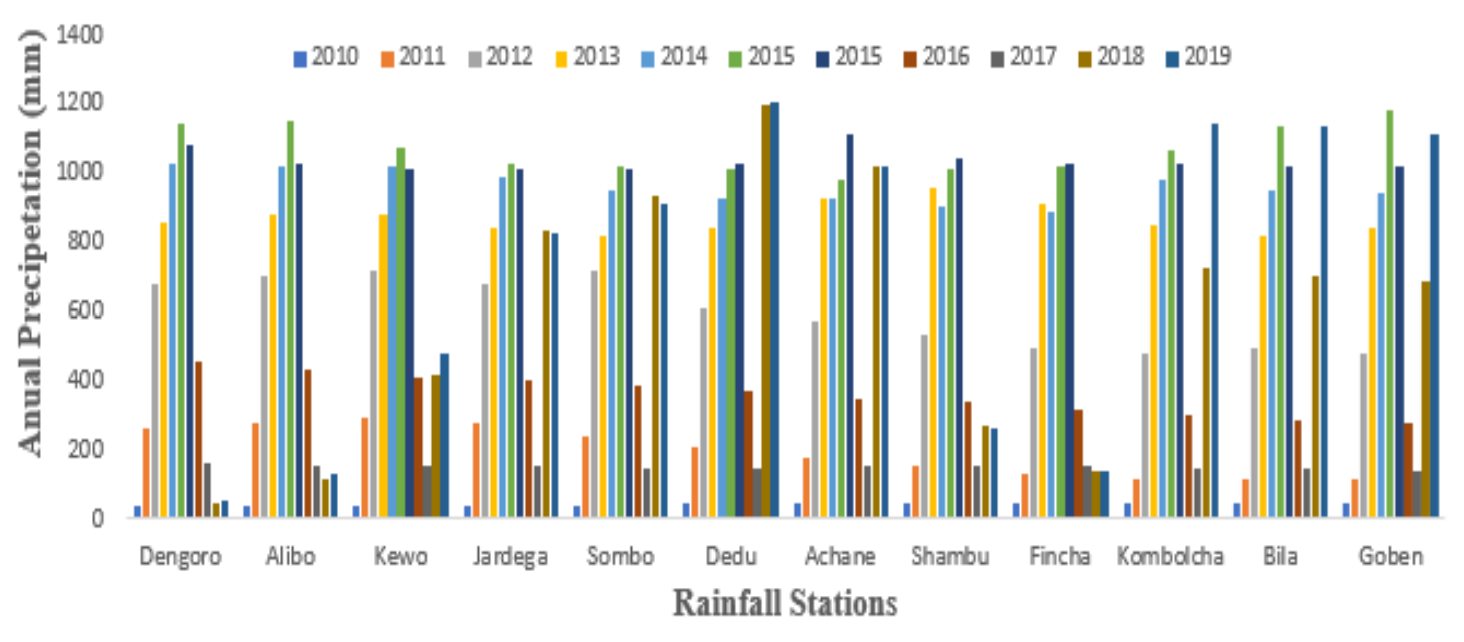

Figure 2: Mean annual precipitation of stations in and surrounding Fincha catchment

\subsection{Soil Loss Models}

Researches have been widely undertaking for developing a reliable soil loss estimation. Different countries have been attempting to develop empirical equations and other physical-based models that are applicable at local and global levels(Markose \& Jayappa, 2016). EUROPean Soil Erosion Model (EUROPSEM), Limburg Soil Erosion Model (LISEM), Soil and Water Assessment Tool (SWAT), and Water Erosion Prediction Project (WEAP) are commonly used soil loss models by adaptation techniques(Mengistu et al., 2016)(Fayas et al., 2019). RUSLE model is the most popular soil loss estimation model and can be developed in ArcGIS. The map algebra in spatial tool analyst of ArcGIS can easily manipulate the combination of soil loss significant factors by developing a model builder(B. Iticha \& Takele, 2018).

\subsection{RUSLE model}

Of soil loss models, Revised Universal Soil Equation (RUSLE) is a popular and commonly used reliable model for annual soil loss quantification(Birhanu Iticha \& Takele, 2019). In this study, RUSLE was used to generate the spatially varied soil erosion severity map by combining five factors. The thematic maps of the raw input parameters of the significant factors (R-factor, P-factor, K-factor, LS-factor, and C-factor) were prepared with $12.5 \times 12.5 \mathrm{~m}$ spatial resolution. A map algebra algorithm in spatial tool analyst and a model builder (Fig.4) developed in ArcGIS were implemented to combine the significant factors using the RUSLE equation as shown below. The general flowchart showing the detailed procedures and data needed is summarized in (Fig. 3). 


$$
A=R * K * L S * C * P
$$

Where A The total annual soil loss ( $\mathrm{t} /$ ha per year), $\mathrm{t}$ is the thickness of lost soil

$\mathrm{R} \quad$ Rainfall erosivity factor $\left(\mathrm{MJmm} \mathrm{ha}^{-1} \mathrm{~h}^{-1}\right.$ year $^{-1}$ )

$\mathrm{K} \quad$ Soil erodibility factor $\left(\mathrm{t} \mathrm{haMJ} \mathrm{mm}^{-1}\right)$

LS Slope length and steepness factor (dimensionless)

C Over and management factor (dimensionless)

P Support practice factor (dimensionless)

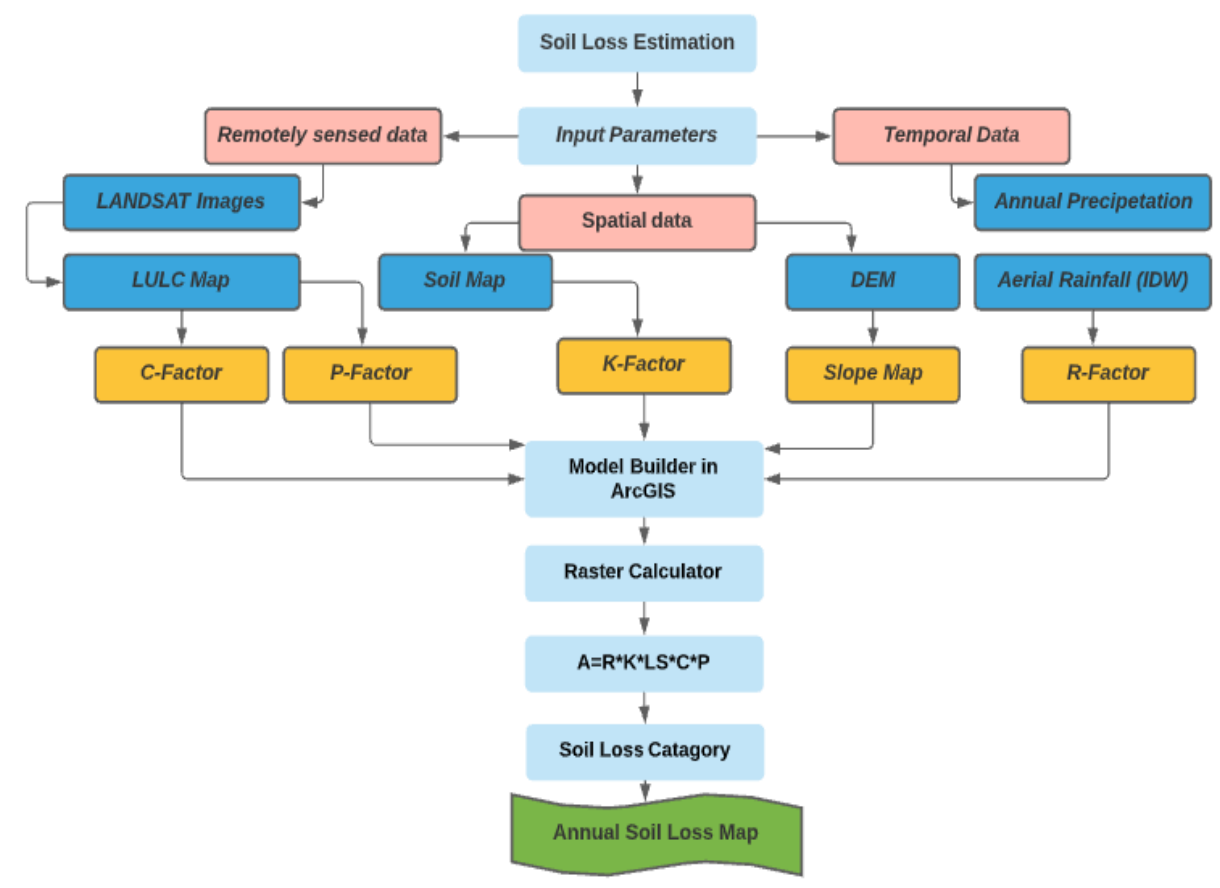

Figure 1: Detail flowchart of the steps and data needed in the study 


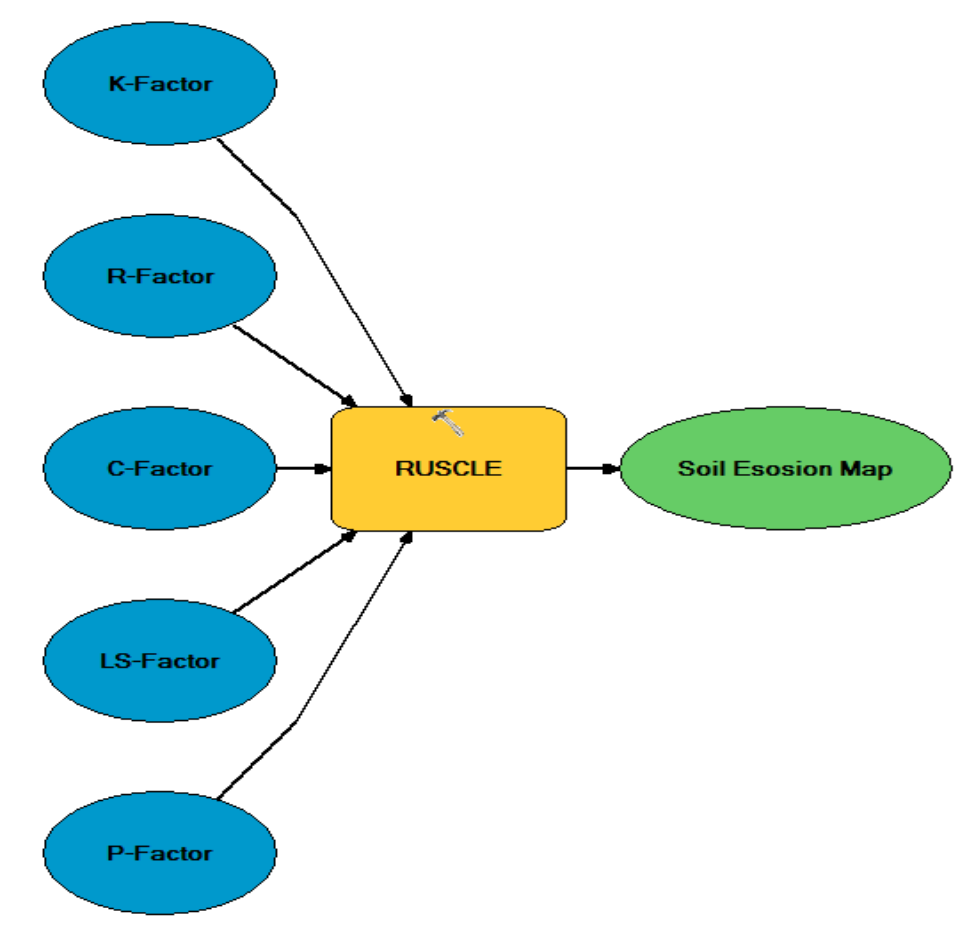

Figure 2: Model builder developed in ArcGIS for combination of the significant factors

\subsection{Rainfall erosivity factor $(R)$}

The rainfall erosivity factor $(\mathrm{R})$ describes the relationship between the rainfall intensity and the soil responses to it(Prasannakumar et al., 2012)(Abdulkadir et al., 2019). In this catchment, the spatial variability of the intensity of the rainfall varies from $1353.65 \mathrm{~mm}$ to $2030.93 \mathrm{~mm}$. There is a positive relationship between the intensity of the precipitation and the soil characteristics in such a way that if the intensity is very high, there is the probability of severe soil erosion(Yesuph \& Dagnew, 2019). Ten years of historical mean annual precipitation of 11 stations contributing to the catchment were considered in this study to generate information about erosivity in the area. An aerial raster geodatabase of rainfall was generated from the point rainfall historical data using Inverse Distance Weight (IDW) interpolation technique(Dessalegn et al., 2017) with 12.5 x $12.5 \mathrm{~m}$ spatial resolution using the regression equation developed by (Eq.2)

$$
R=1.24 * P^{1.36}
$$

Where $\quad \mathrm{R}$ Rainfall erosivity factor $\left(\mathrm{MJmm} \mathrm{ha}^{-1} \mathrm{~h}^{-1}\right.$ year $\left.^{-1}\right)$

$\mathrm{P} \quad$ Annual mean precipitation $(\mathrm{mm})$

\subsection{Soil Erodibility factor $(\mathrm{K})$}

The properties of soil and the degree of erodibility are interconnected parameters. When the drop of rainfall hits the soil particles, there is a high probability of disintegration in soil particles when the soil hitting external force exceeds the cohesion forces between soil particles(Kayet et al., 2018). The ability of soil particles in persisting against rainfall is 
different in different soil types and this property is expressed in terms of erodibility factor(Ayenew et al., 2018). In this catchment there are more than 10 soil types are available and reclassified into 6 dominant types (Fig. 5 and Table 2) and k-values were assigned.

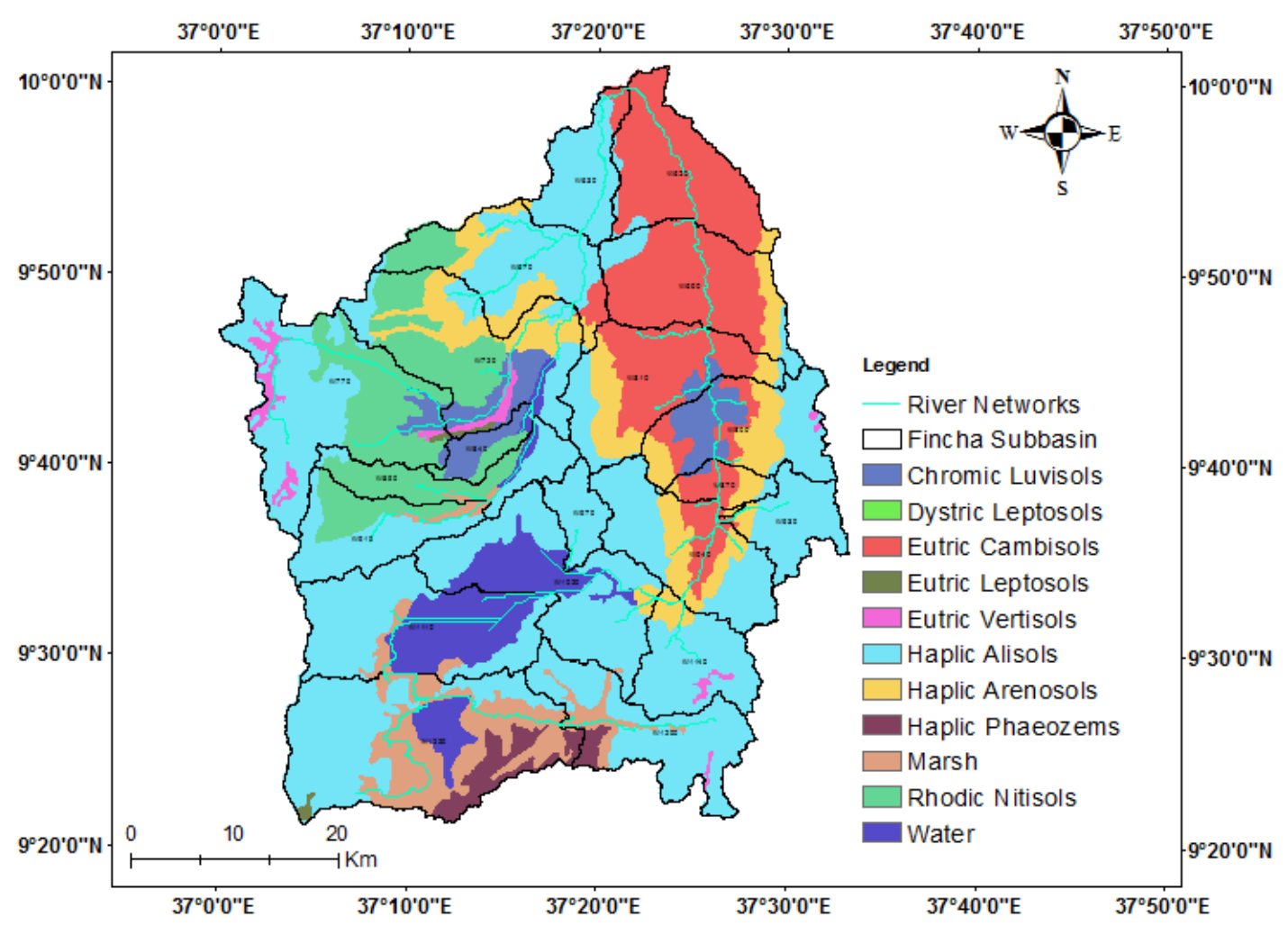

Figure 3: Soil types in the Catchment

Table 2: Soil types and corresponding erodibility factor (k-values) in the catchment

\begin{tabular}{lccc}
\hline \multicolumn{1}{c}{ Soil Types } & K-factor value & Area $\left(\mathbf{K m}^{\mathbf{2}}\right)$ & Area $(\boldsymbol{\%})$ \\
\hline Chromic Luvisos & 0.27 & 3.71 & 17.27 \\
Dystric Leptosols & 0.68 & 0.74 & 3.45 \\
Eutric Cambisols & 0.35 & 4.57 & 21.28 \\
Eutric Leptosols & 0.34 & 0.54 & 2.51 \\
Eutric Vertisols & 0.24 & 2.42 & 11.27 \\
Haplic Alisols & 0.45 & 8.58 & 39.94 \\
Haplic Arenosols & 0.67 & 0.25 & 1.16 \\
Haplic Phaeozems & 0.21 & 0.14 & 0.65 \\
Marsh & 0.24 & 0.09 & 0.42 \\
Rhodic Nitisols & 0.34 & 0.44 & 2.05 \\
\hline
\end{tabular}

\subsubsection{Topographic Factor (LS)}

The severity of the spatial variability of soil erosion highly relies on the topographic conditions of an area. The steepness or the flatness of an agricultural land governs the 
degree of the erodibility of soil particles. The speed of the water flowing over soil and the slope of the topography are dependent parameters(Kayet et al., 2018). The length of the slope and slope steepness of the area in the study area was generated using Digital Elevation Model (DEM) of 12.5 x 12.5m spatial resolution and LS-factor was generated in ArcGIS version 10.4. Flow accumulation and slope (\%) are commonly used input parameters with a fixed cell size with regression equation(Abdulkadir et al., 2019) (Eq.3).

$$
\begin{gathered}
L S=\left\{\text { Flow accumalation } *\left(\frac{\text { Cell size }}{23.13}\right)\right\}^{0.4} *\left\{\frac{\sin (\text { slope }(\%) * 0.01745)}{0.09}\right\}^{1.3} \\
* 1.6 \ldots \ldots . .(3)
\end{gathered}
$$

Where LS Slope length and steepness factor (dimensionless)

\subsection{Cover and Management factor $(C)$}

The types of cover and land use in agricultural land is highly interrelated factors. Raw input DEM was corrected by applying fill and flow direction in ArcGIS using spatial tool analyst. Slope (\%) and flow accumulation were generated for the study area and reclassified based on the c-values in spatial tool analyst. The types of land use land cover (LULC) in the study area (Fig.7) and the corresponding c-values (Table 3) were assigned. In the same fashion, the values for support practice factor $(\mathrm{P})$ were generated from the land use land cover map.

Table 3: Cover and Management (C) and Support practice (P) factors in the study area

\begin{tabular}{lll}
\hline Land Use & C-Factor Value & P-factor value \\
\hline Trees cover areas & 0.25 & 0.27 \\
Shrub cover areas & 0.37 & 0.68 \\
Grass Land & 0.45 & 0.87 \\
Crop Land & 0.68 & 0.48 \\
Swampy areas & 0.75 & 0.91 \\
Breland & 0.65 & 0.57 \\
Built-up areas & 0.47 & 0.67 \\
Open water & 0.66 & 0.69 \\
\hline
\end{tabular}

\section{RESULT AND DISCUSSIONS}

\subsection{Soil Loss Quantification in Fincha catchment}

The quantified annual soil loss values are generally ranging from 0 to 76.5 in thickness (t) soil per hectare per year. The total area of this particular catchment is $21.48 \mathrm{~km} 2$ (2148 ha) and this indicates that 164, $322 \mathrm{t} /$ ha per year quantity of soil is lost and a similar soil loss estimation was made in the study conducted by [12][6]. The qualitative based 
classifications namely; very high, high, moderate, low, and very low for identification spatial variation of soil erosion severity applied in [8][1][9] was also repeated in this study. The area covered in the percentage of soil erosion severity of $10 \%, 45 \%, 30 \%$, and $15 \%$ as low, moderate, high, and very high respectively were identified (Fig. 5). As revealed in the severity map generated using the RUSLE model (Fig. 13), the agricultural lands which cover $65 \%$ (13.96 ha) of the total area are highly vulnerable to erosion and the qualitative classification of the area is between high to very high to the soil loss risk. The effect of the erosion is very visible in this catchment when compared to estimated soil loss in other catchments [4]. In terms of the significant factors; rainfall erosivity (Rfactor), cover and management(C-factor), and support and conservation practice ( $\mathrm{P}$ factor) factors revealed high significance while the other factors are relatively low significant for the initiation of soil erosion, and the values of the corresponding factors were shown in Fig.6-8 respectively. The spatial variability of mean annual rainfall shown in (Fig.6) showed that the majority of croplands and soil types in the lower part of the catchment is very sensitive to soil loss and this fact is observed in the severity map (Fig.13). The rate of soil loss seen in the catchment is higher than the total annual soil formation rate ranges from 2 to 22 t/ha per year for the different land uses units of Ethiopia [8] and special attention should be given to minimize the rate of soil loss in the catchment by implementing soil formation strategies or soil and resources management strategies. Support and conservation practices factor (P-factors) values were assigned based on the soil types in the study area. The soil map was reclassified into six dominant soil types and the corresponding p-factor values were given (Fig. 11). 


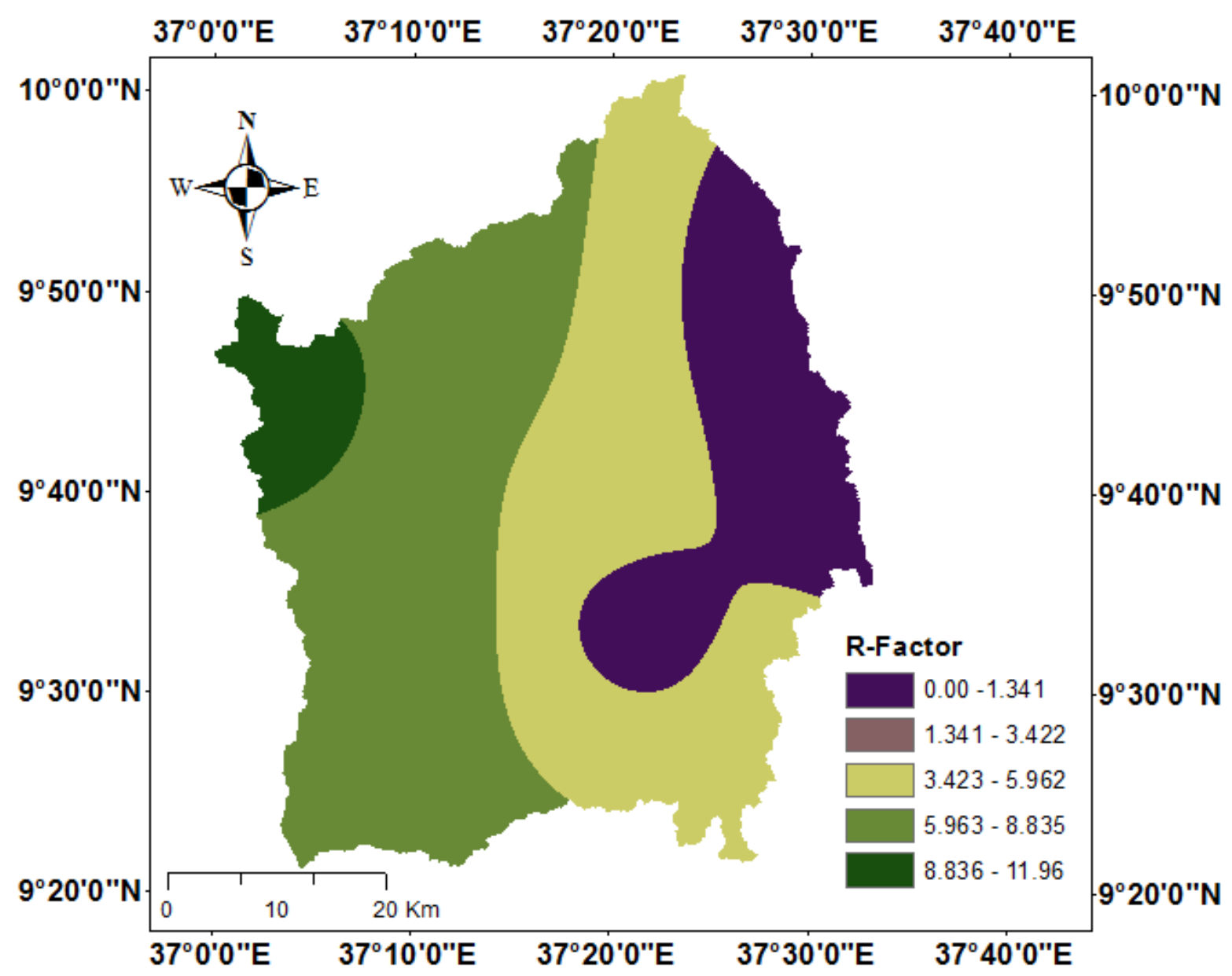

Figure 4: Rainfall erosivity factor (R-factor) values in Fincha catchment

The low-land agricultural areas in this catchment are less vulnerable to soil erosion and relatively less soil loss is visible[16] due to the low velocity of runoff water. The traditional way of agricultural systems and soil conservation practices is very weak in the lower part of the study area, therefore, the support and conservation practices factor (p-factor) reveals that the croplands and bare land are very exposed and sensitive to erosion due to the incoming runoff water from the highland areas[16]; Kayet et al., 2018). 


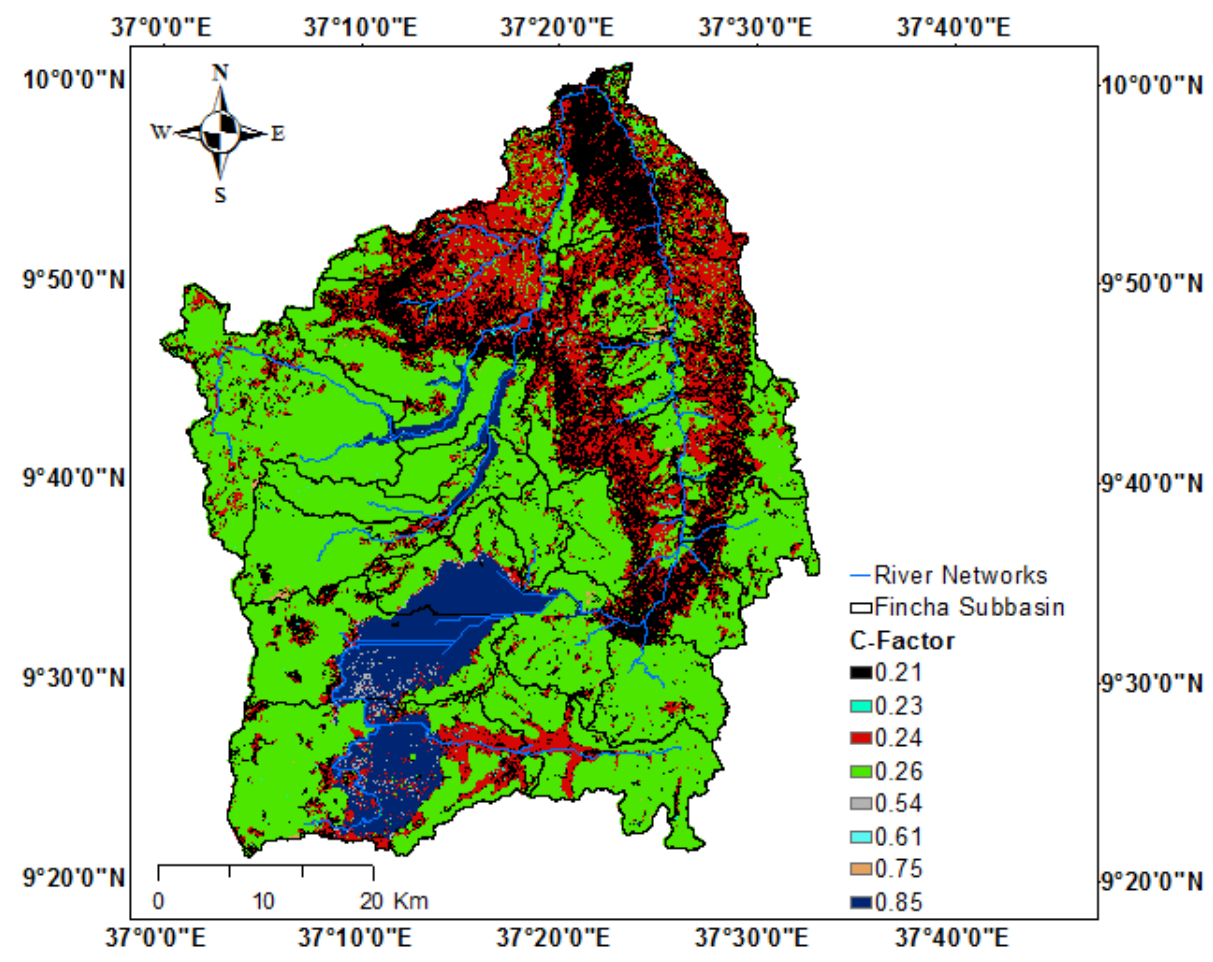

Figure 5: Major land use land cover (LULC) types and corresponding C-values

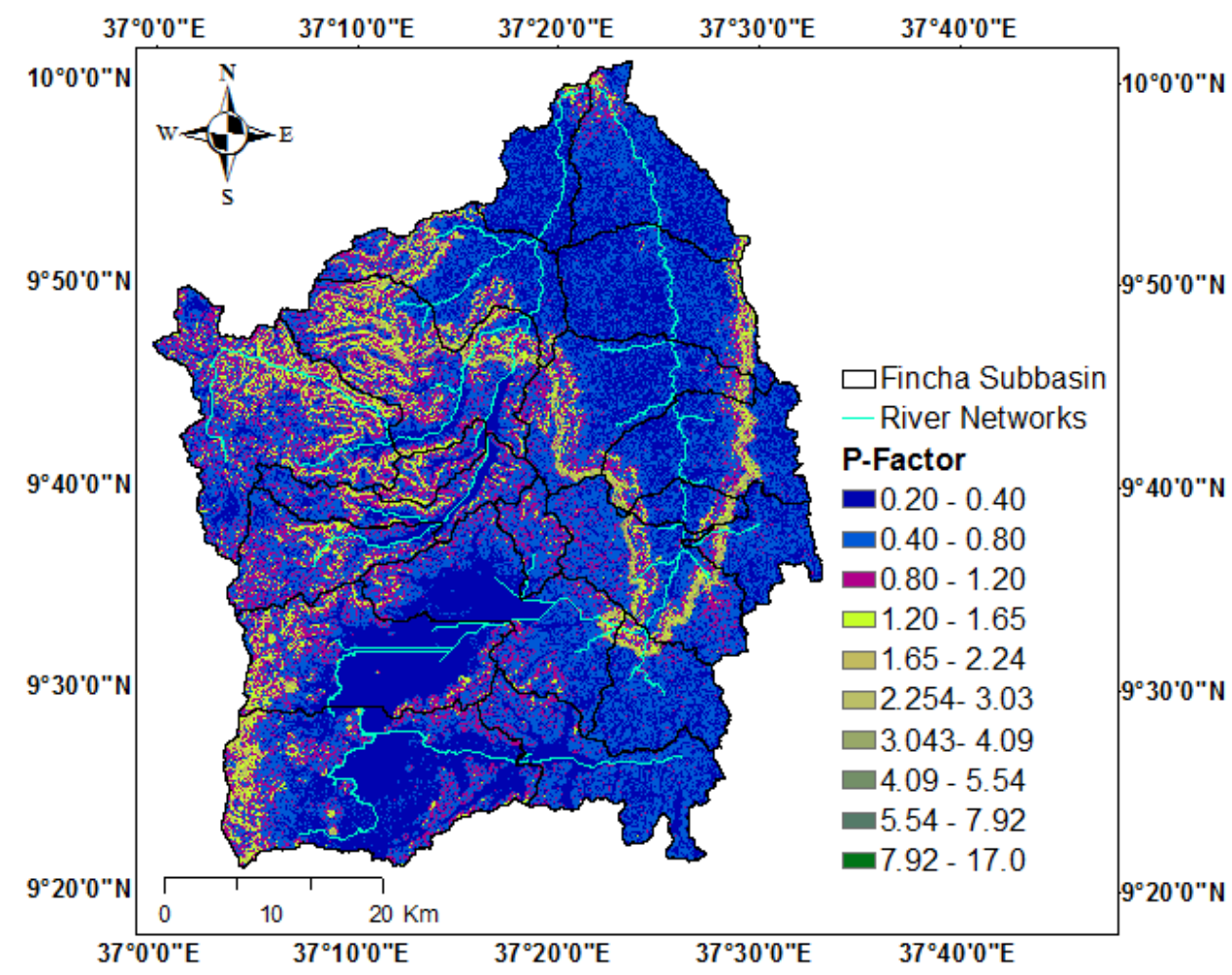

Figure 6: Support and practice factor (P-factor) values in Fincha catchment

The slope length and steepness (LS) is also another factor that describes the sensitivity of soil to erosion that governs the velocity of runoff water exerting high pushing forces on the soil particles and causing detachment of soil particles, which in turn lead to 
erosion. In this catchment, the slope ranges from 0 to $79.9 \%$, and due to the steepness of the slope, the soil loss is very visible especially for the slope values of more than $11 \%[6]$. The ranges of slope in degree (Fig.9) and the corresponding LS-factor values were generated (Fig.10) according to the studies conducted by (Dinka, 2020;Thapa, 2020). A model builder for the RUSLE model was developed and raster map algebra was applied in ArcGIS version 10.4 to quantify the total annual soil loss. It was found that the quantified average annual soil loss (Fig.13) which ranges from 0.0 to $76.5 \mathrm{t}$ ha- $1 \mathrm{yr}-$ 1 was obtained in the catchment. In this study, qualitative classification based five erosion severity classes as very high (> $45 \mathrm{t}$ ha -1 year -1$)$, high $(30-45 \mathrm{t}$ ha -1 year -1$)$, moderate (15-30 tha -1 year -1-), low (0-15 t ha -1 year -1-) were identified (Fig.12 and Fig. 14). The spatial variation of the soil loss severity map generated in the RUSLE model has a paramount role to alert land resources managers and all stakeholders in controlling the effects via the implementation of both structural and non-structural mitigations. The results of the RUSLE model can also be further considered along with the catchment for practical soil loss quantification that can help for protection practices.

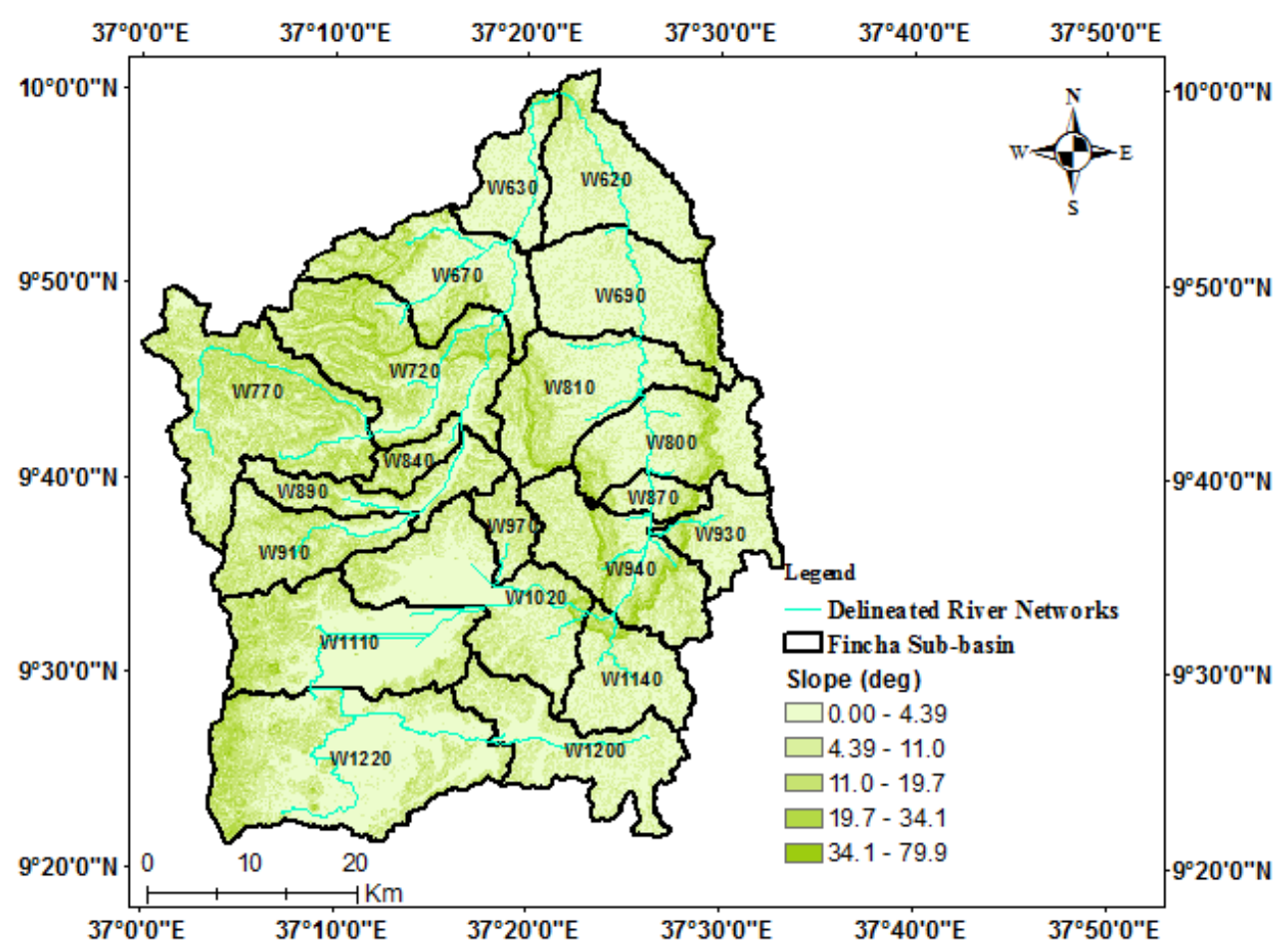

Figure 7: The range of Slope in Fincha Catchment (derived from DEM (12.5m x $12.5 \mathrm{~m})$ 


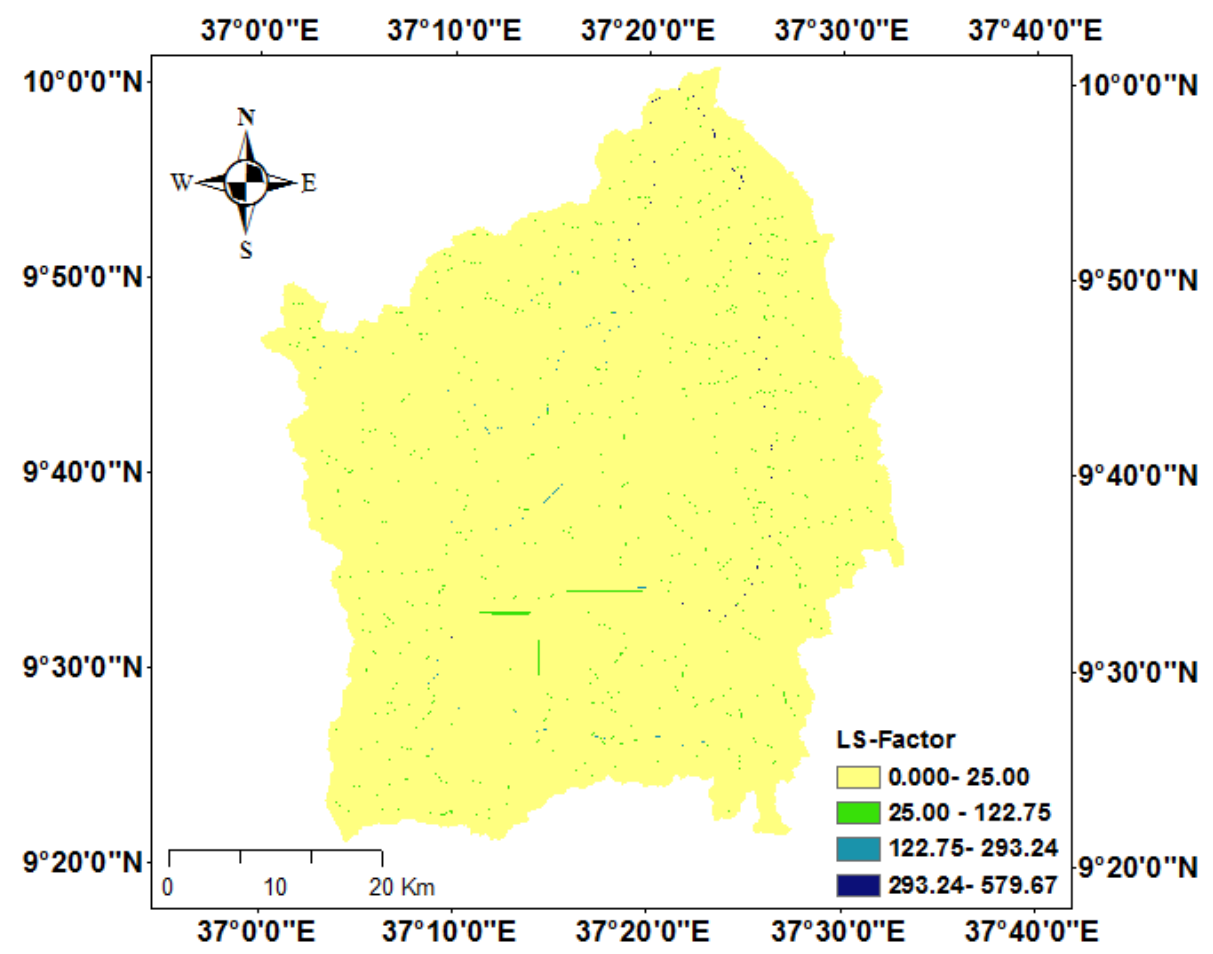

Figure 8: LS factor generated from slope (\%) at $12.5 \mathrm{~m} \times 12.5 \mathrm{~m}$ spatial resolution

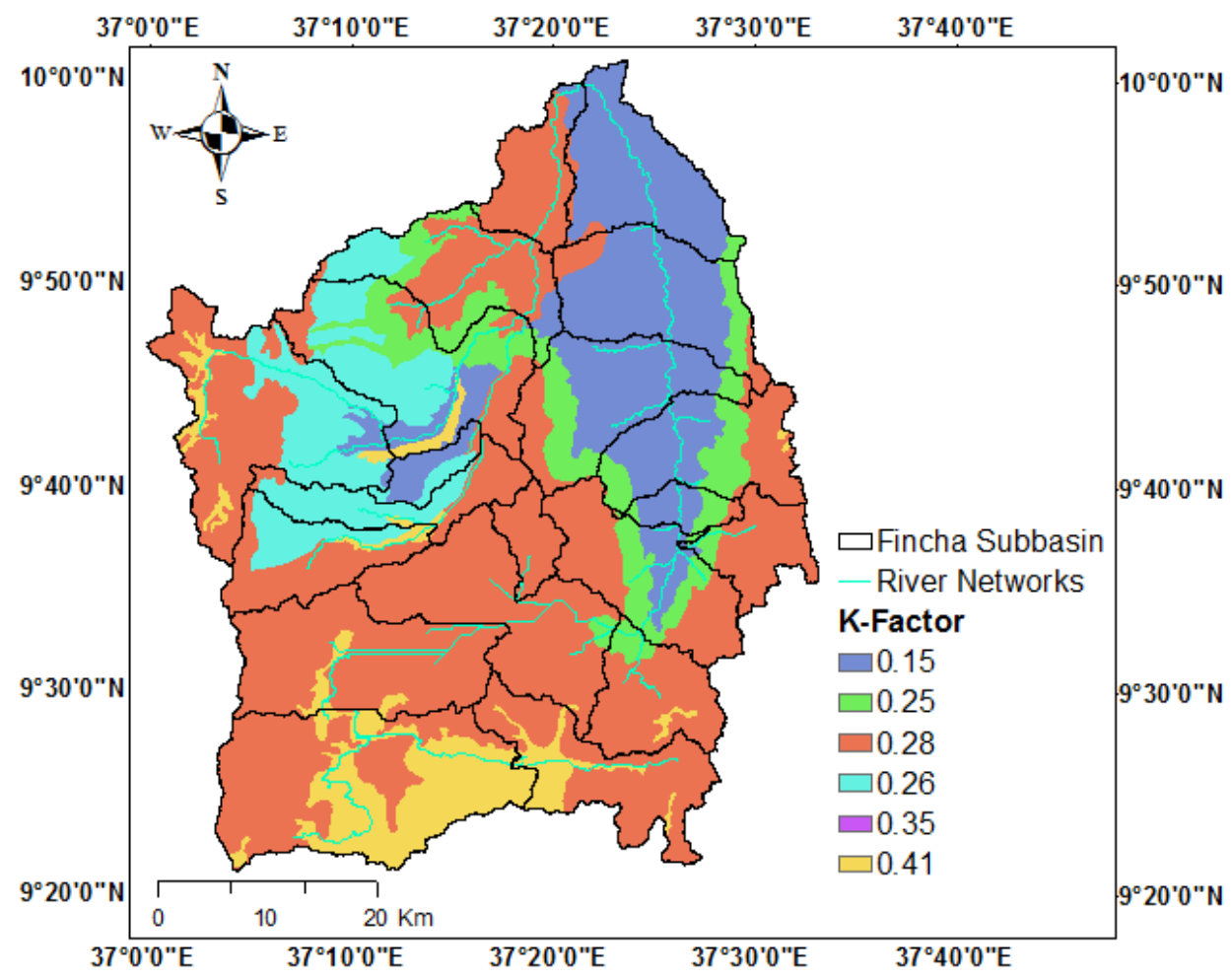

Figure 9: Soil erodibility factor generated from major soil types in Fincha catchment 


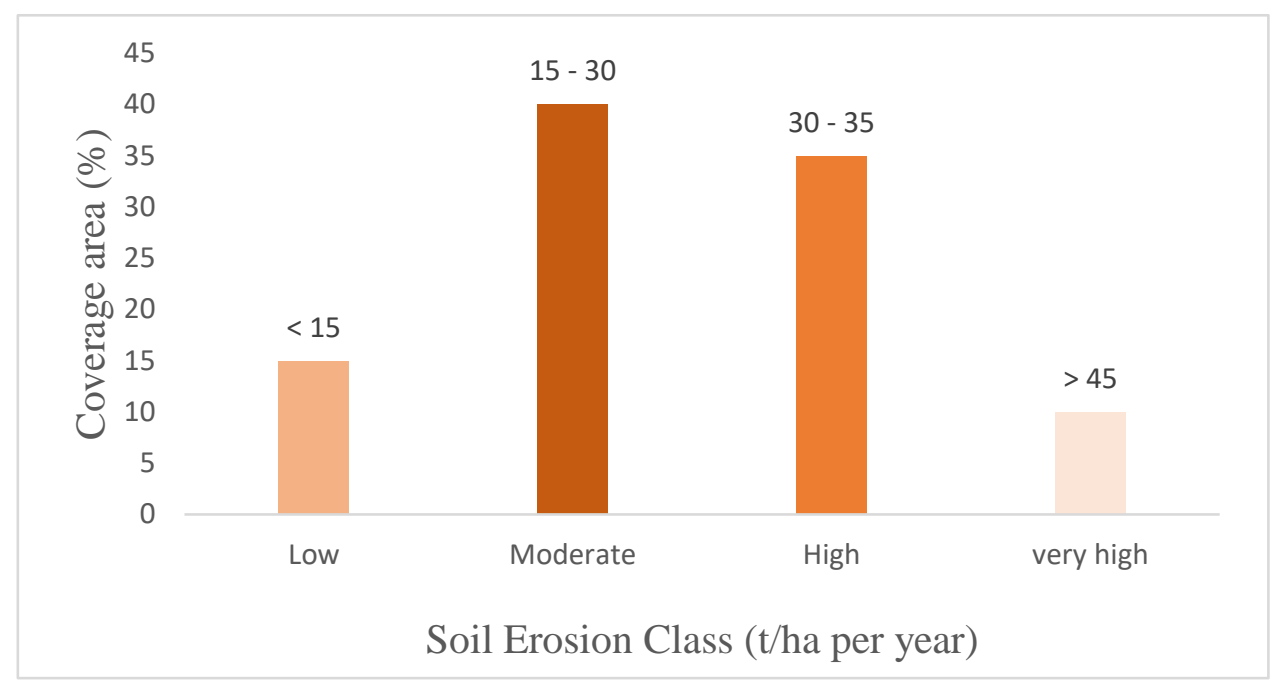

Figure 10: Soil Erosion class in the catchment

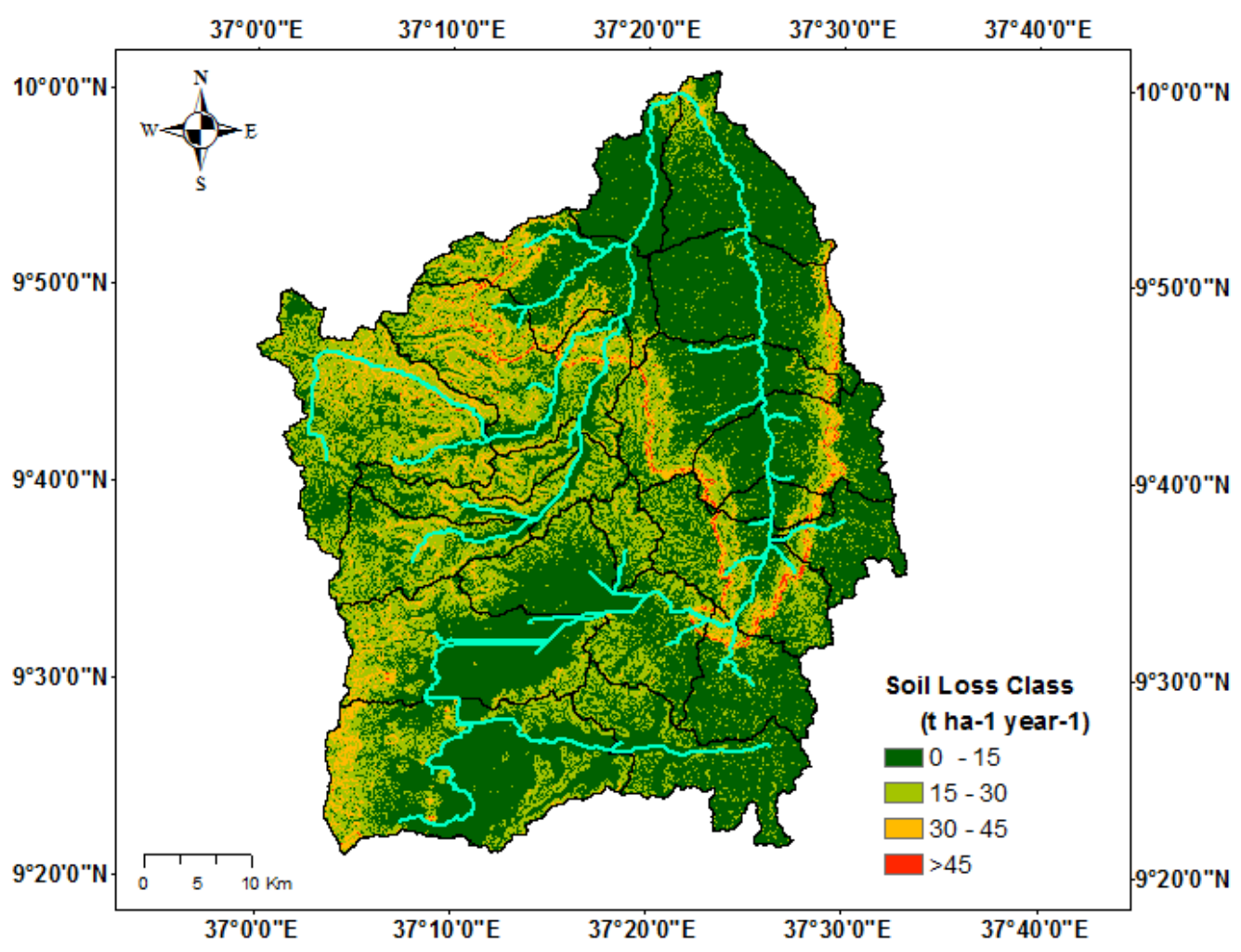

Figure 11: Soil loss classification map of Fincha catchment 


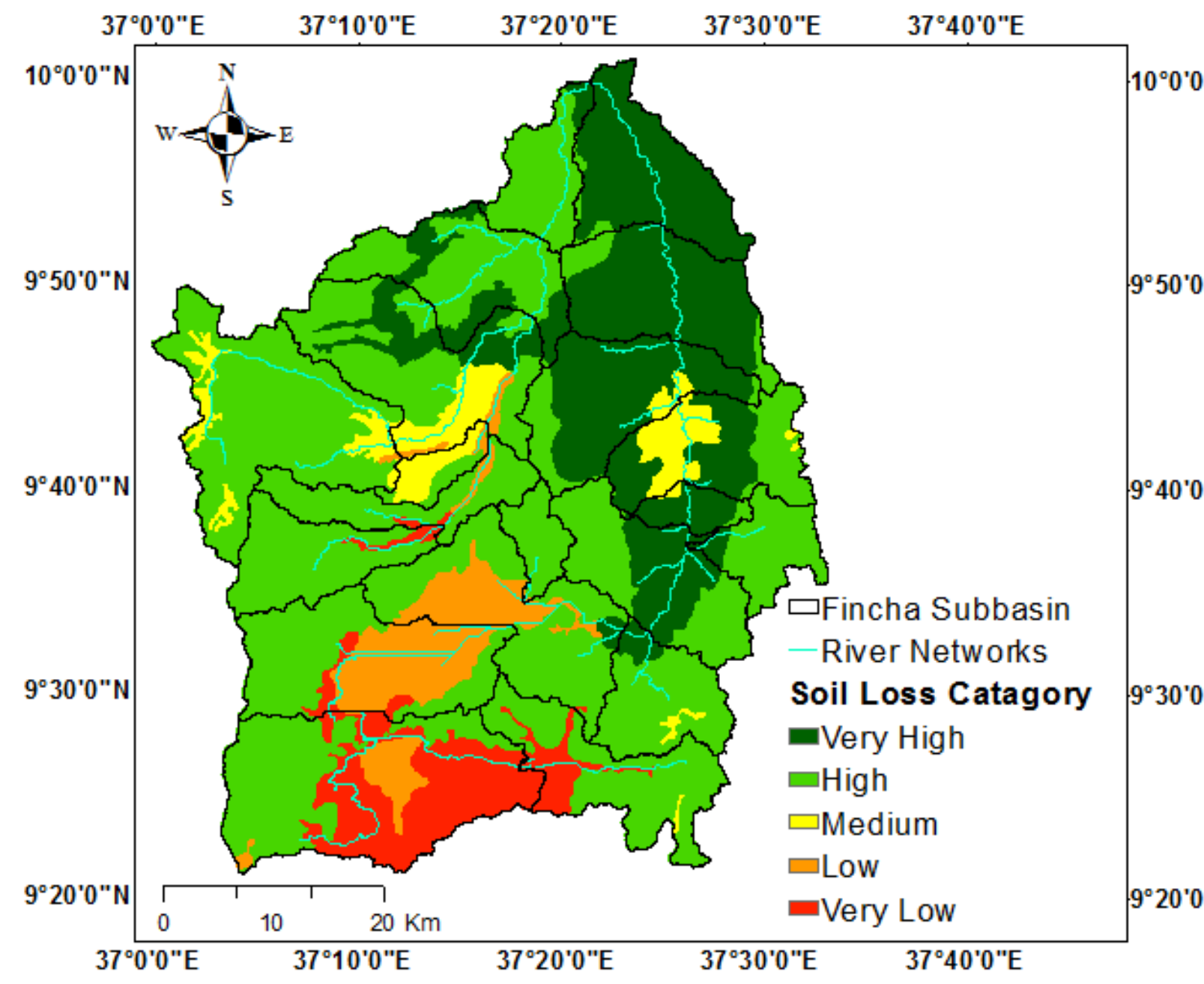

Figure 12: Qualitative based spatial variation of soil erosion severity map in Fincha catchment

\section{Conclusion}

The quantification of soil loss using an integrated RUSLE model and GIS is successfully provided a qualitative classification-based identification of soil loss severity understandings in Fincha catchment of Abay river basin in Ethiopia. In general, five erosion severity classes as very high (> $45 \mathrm{t}$ ha -1 year -1$)$, high $(30-45 \mathrm{t}$ ha -1 year -1$)$, moderate (15-30 tha -1 year -1-), low (0-15 t ha -1 year -1-). The soil erosion-prone areas map generated in this catchment provides necessary information for soil and land resources management practices for the implementation of either structural or nonstructural soil conservation measures. From this study, it was found that the upper and the low-lying areas are highly vulnerable to soil erosion and a soil conservation strategy should be implemented to control the loss of top fertile soil in the catchment. Additionally, capacity building training should be given for the farmers and soil conservation experts to minimize the man-made soil loss driving factors such as 
deforestation and traditional way of farming practices. Finally, it was concluded that having information about the spatial variability of soil loss severity map generated in the RUSLE model has a paramount role to alert land resources managers and all stakeholders in controlling the effects via the implementation of both structural and non-structural mitigations. The results of the RUSLE model can also be further considered along with the catchment for practical soil loss quantification that can help for protection practices.

\section{REFERENCES}

Abdulkadir, T. S., Muhammad, R. U. M., Wan Yusof, K., Ahmad, M. H., Aremu, S. A., Gohari, A., \& Abdurrasheed, A. S. (2019). Quantitative analysis of soil erosion causative factors for susceptibility assessment in a complex watershed. Cogent Engineering, 6(1). https://doi.org/10.1080/23311916.2019.1594506

Ayenew, B., Taddesse, A. M., Kibret, K., \& Melese, A. (2018). Chemical forms of phosphorous and physicochemical properties of acid soils of Cheha and Dinsho districts, southern highlands of Ethiopia. Environmental Systems Research, 7(1). https://doi.org/10.1186/s40068-018-0118-9

Borrelli, P., Robinson, D. A., Panagos, P., Lugato, E., Yang, J. E., Alewell, C., Wuepper, D., Montanarella, L., \& Ballabio, C. (2020). Land use and climate change impacts on global soil erosion by water (2015-2070). Proceedings of the National Academy of Sciences of the United States of America, 117(36), 2199422001. https://doi.org/10.1073/pnas.2001403117

Dessalegn, T. A., Moges, M. A., Dagnew, D. C., \& Gashaw, A. (2017). Applicability of Galway River Flow Forecasting and Modeling System (GFFMS) for Lake Tana Basin, Ethiopia. Journal of Water Resource and Protection, 09(12), 1319-1334. https://doi.org/10.4236/jwarp.2017.912084

Dinka, M. O. (2020). Quantification of soil erosion and sediment yield for ungauged catchment using the RUSLE model: Case study for Lake Basaka catchment in Ethiopia. Lakes and Reservoirs: Research and Management, 25(2), 183-195. https://doi.org/10.1111//re.12312

Enea, A., Alexandru, U., Cuza, I., Urzica, A., Alexandru, U., Cuza, I., Alexandru, U., \& Cuza, I. (2018). Remote sensing, gis and hec-ras techniques, applied for flood extent validation, based on landsat imagery, lidar and hydrological data . Case study: Baseu river , Romania LANDSAT IMAGERY, LIDAR AND HYDROLOGICAL DATA . November.

Fayas, C. M., Abeysingha, N. S., Nirmanee, K. G. S., Samaratunga, D., \& 
Mallawatantri, A. (2019). Soil loss estimation using rusle model to prioritize erosion control in KELANI river basin in Sri Lanka. International Soil and Water Conservation Research, 7(2), 130-137. https://doi.org/10.1016/j.iswcr.2019.01.003

Girmay, G., Moges, A., \& Muluneh, A. (2020). Estimation of soil loss rate using the USLE model for Agewmariayam Watershed, northern Ethiopia. Agriculture and Food Security, 9(1), 1-12. https://doi.org/10.1186/s40066-020-00262-w

Hategekimana, Y., Allam, M., Meng, Q., Nie, Y., \& Mohamed, E. (2020).

Quantification of soil losses along the coastal protected areas in Kenya. Land, 9(5), 1-16. https://doi.org/10.3390/LAND9050137

Iticha, B., \& Takele, C. (2018). Soil-landscape variability: mapping and building detail information for soil management. Soil Use and Management, 34(1), 111-123. https://doi.org/10.1111/sum.12404

Iticha, Birhanu, \& Takele, C. (2019). Digital soil mapping for site-specific management of soils. Geoderma, 351(August 2018), 85-91. https://doi.org/10.1016/j.geoderma.2019.05.026

Kayet, N., Pathak, K., Chakrabarty, A., \& Sahoo, S. (2018). Evaluation of soil loss estimation using the RUSLE model and SCS-CN method in hillslope mining areas. International Soil and Water Conservation Research, 6(1), 31-42. https://doi.org/10.1016/j.iswcr.2017.11.002

Markose, V. J., \& Jayappa, K. S. (2016). Soil loss estimation and prioritization of subwatersheds of Kali River basin, Karnataka, India, using RUSLE and GIS. Environmental Monitoring and Assessment, 188(4). https://doi.org/10.1007/s10661-016-5218-2

Mengistu, D. T., Moges, S. A., \& Sorteberg, A. (2016). Revisiting Systems Type BlackBox Rainfall-Runoff Models for Flow Forecasting Application. January, 65-83.

Panagos, P., Standardi, G., Borrelli, P., Lugato, E., Montanarella, L., \& Bosello, F. (2018). Cost of agricultural productivity loss due to soil erosion in the European Union: From direct cost evaluation approaches to the use of macroeconomic models. Land Degradation and Development, 29(3), 471-484. https://doi.org/10.1002/ldr.2879

Prasannakumar, V., Vijith, H., Abinod, S., \& Geetha, N. (2012). Estimation of soil erosion risk within a small mountainous sub-watershed in Kerala, India, using 
Revised Universal Soil Loss Equation (RUSLE) and geo-information technology. Geoscience Frontiers, 3(2), 209-215. https://doi.org/10.1016/j.gsf.2011.11.003

Singh, G., \& Panda, R. K. (2017). Grid-cell based assessment of soil erosion potential for identification of critical erosion prone areas using USLE, GIS and remote sensing: A case study in the Kapgari watershed, India. International Soil and Water Conservation Research, 5(3), 202-211. https://doi.org/10.1016/j.iswcr.2017.05.006

Thapa, P. (2020). Spatial estimation of soil erosion using RUSLE modeling: a case study of Dolakha district, Nepal. Environmental Systems Research, 9(1). https://doi.org/10.1186/s40068-020-00177-2

Yan, R., Zhang, X., Yan, S., \& Chen, H. (2018). Estimating soil erosion response to land use/cover change in a catchment of the Loess Plateau, China. International Soil and Water Conservation Research, 6(1), 13-22. https://doi.org/10.1016/j.iswcr.2017.12.002

Yesuph, A. Y., \& Dagnew, A. B. (2019). Soil erosion mapping and severity analysis based on RUSLE model and local perception in the Beshillo Catchment of the Blue Nile Basin, Ethiopia. Environmental Systems Research, 8(1), 1-21. https://doi.org/10.1186/s40068-019-0145-1 